\title{
CULTURAL TOURISM AND WORLD HERITAGE
}

\section{KULTURNÍ CESTOVNÍ RUCH A SV'rTOVÉ D'rDICTVÍ}

\section{Ing. PATRIK KAJZAR, PH.D.}

\author{
Katedra cestovního ruchu $\mid$ Department of Tourism \\ Obchodn Пpodnikatelská fakulta v Karviné School of Business Administration in Karvina \\ Slezská univerzita v Opav $\mid$ Silesian University in Opava \\ $\bowtie$ Univerzitní nám. 1934/3, 73340 Karviná, Czech Republic \\ E-mail: kajzar@opf.slu.cz
}

\begin{abstract}
Annotation
According to the UNWTO document ñTourism 2020 Visionò cultural tourism belongs to the most popular forms of tourism and the interest in it grows faster than in other forms of tourism. Its growth rate is even faster that the growth of global tourism. Cultural tourism is often intertwined with other forms of tourism, especially with spa, medical, recreational and congress tourism. Cultural tourism is often associated with visiting of cultural destination, which is such a destination, which is the goal of cultural tourism and the culture is significantly or dominantly applied in its offer. World Heritage is the designation for places on Earth that are of outstanding universal value to humanity and as such, have been inscribed on the World Heritage List to be protected for future generations to appreciate and enjoy. The aim of this paper is to evaluate cultural tourism in connection with World Heritage.
\end{abstract}

\section{Key words}

cultural tourism, UN World Tourism Organisation, cultural tourists, World Heritage

\section{Anotace}

Podle dokumentu SvПové organizace cestovního ruchu, UNWTO "Vize cestovního ruchu pro rok 2020", kulturní cestovní ruch patŚ k nejoblíben Đğm formám cestovního ruchu a zájem o $n \bigvee$ roste

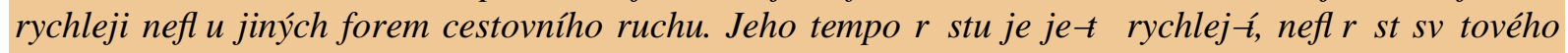
cestovního ruchu. Kulturní cestovní ruch se l̦ asto prolíná s dalġmi formami cestovního ruchu, a to zejména s lázenským, zdravotním, rekrea!̣ ním a kongresovým cestovním ruchem. Kulturní cestovní ruch je !̣asto spojován s návğ円ou kulturních destinací, coǵ je taková destinace, která je cílem

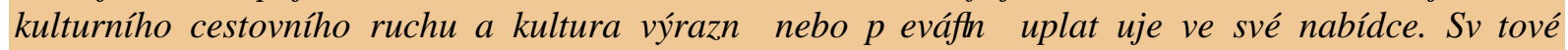
dhlictví je oznal ení pro místa na Zemi, které mají výjimel nou celosv †ovou hodnotu pro lidstvo a jako takové byly zapsány na Seznam sv hového dhlictví, které je tŚsba chránit pro budoucí generace.

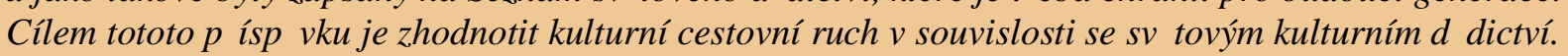

Klị! ová slova

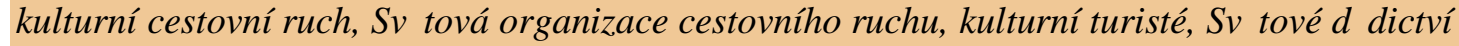

JEL classification: $L 83$

\section{Introduction}

Over the decades, tourism has experienced continued growth and deepening diversification to become one of the fastest growing economic sectors in the world. Modern tourism is closely linked to development and encompasses a growing number of new destinations. These dynamics have turned tourism into a key driver for socio-economic progress. (Zedková, Kajzar 2013)

Cultural tourism gives visitors the opportunity to understand and appreciate the Essentials character of a place and its culture as a whole, including its (Kajzar, 2013): 
- history and archeology,

- people and their lifestyle (including the ways in which they earn a living and enjoy their leisure),

- cultural diversity, arts and architecture,

- food, wine and other local produce,

- social, economic and political structures,

- landscape.

Existence of cultural tourism and tourism travel in general, depends on the unique qualities of cultures around the globe. (Zedková, Kajzar 2013)

Cultural tourism is an inevitable component of cultural heritage. The UN World Tourism Organisation (UNWTO) is the leading international body for the Tourism Sector. In cooperation with many public and private sector stakeholders UNWTO strives for the development and promotion of sustainable tourism.(Brooks, 2011)

The aim of this paper is to evaluate cultural tourism in connection with World Heritage. Author used secondary sources and general-theoretical scientific methods analysis, induction and comparing.

\section{Cultural tourism}

The concept of cultural tourism again is very complex and so there is a long debate among scholars about its definition and conceptualisation due to which we find numerous definitions for this term. So as one of the most important recent papers on cultural tourism $\ddot{~}$ more exactly cultural city tourism $\ddot{I}$ mentions, ñthere are a great number of definitions of cultural tourism in use, resulting in different definitions being used in research studies related to cultural tourism and in the field of cultural tourism.ò (Csapó, 2012)

Cultural tourism is defined by McIntosh and Goeldner as comprising "all aspects of travel, whereby travellers learn about the history and heritage of others or about their contemporary ways of life or thought. (Richards, 2005)

According to the International Scientific Committee on Cultural Tourism, cultural tourism can be defined as that activity which enables people to experience the different ways of life of other people, thereby gaining at first hand an understanding of their customs, traditions, the physical environment, the intellectual ideas and those places of architectural, historic, archaeological or other cultural significance which remain from earlier times. Cultural tourism differs from recreational tourism in that it seeks to gain an understanding or appreciation of the nature of the place being visited.ò

The typical cultural tourists are people aged 45 ï 60 . Most of them are people with higher incomes and education and they are willing to spend more money on their trips. They are sophisticated people who look for new experiences and new destinations. It is assumed that the number of people interested in cultural tourism will grow with how baby-boom generation matures. It will show not only in the interest in the classical cultural destinations, but also in the developing countries whose cultural products will improve the quality and profit from the growth of segments. Cultural destinations should offer such cultural products, which will be a story and experience for their visitors. (Zedková, Kajzar 2013)

It is important that destination managers understand both the travel motivation and the type of experience that different types of cultural tourists are seeking. (Fig. 1) Therefore, for market segmentation purposes each of the five categories of cultural tourist may be described as follows. (Williams, 2010)

- Purposeful cultural tourist $\ddot{i}$ cultural tourism is the primary motivation for visiting a specific destination and the tourist seeks a very deep experience:

- Sightseeing cultural tourist $\ddot{i}$ cultural tourism is a key reason for visiting a specific destination but the experience is less deep. 
- Serendipitous cultural tourist $\ddot{i}$ the tourist does not travel for specific cultural reasons, but ultimately does have a deep cultural tourism experience.

- Casual cultural tourist ï cultural tourism is a weak travel motivation and the resulting cultural experience is shallow.

- Incidental cultural tourist $і ̈$ the tourist does not travel for cultural reasons, but does engage in some cultural activities and has shallow experiences.

Fig. 1: Cultural Tourists Typology

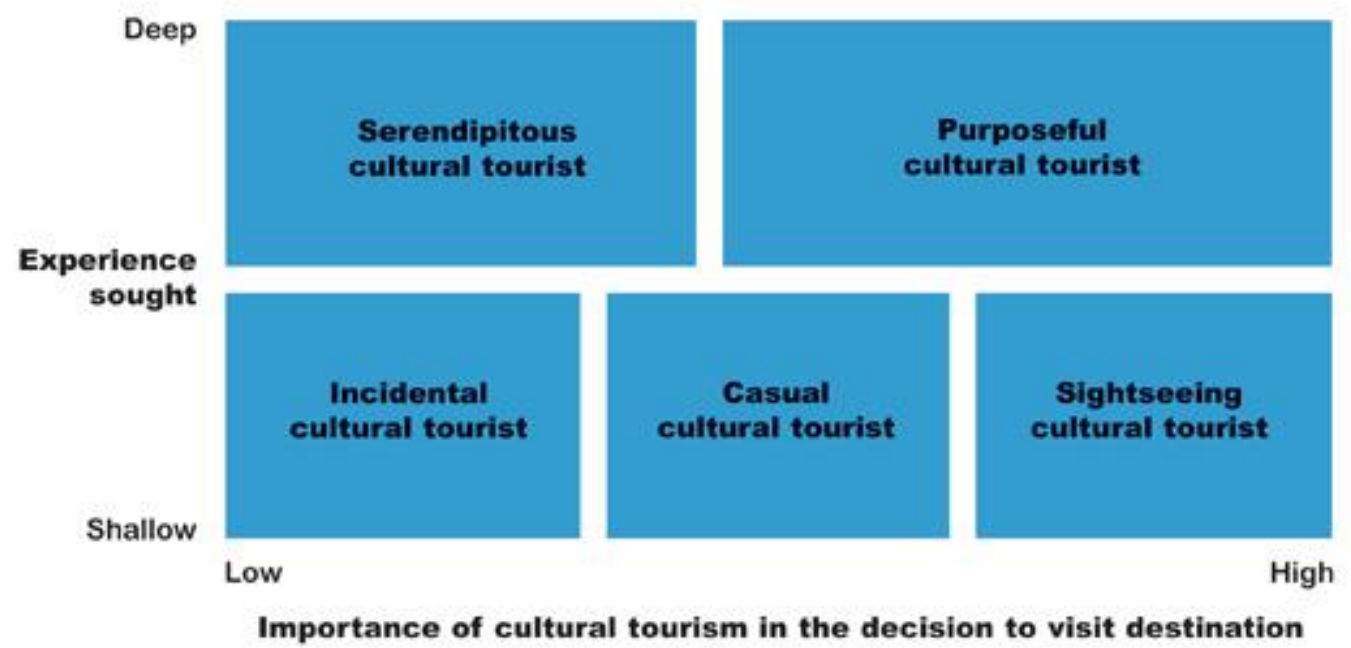

Source: Williams, 2010.

Cultural tourism we can dividend into:

- Heritage tourism ( Natural and cultural heritage - very much connected to nature-based or ecotourism);

- Cultural thematic routes ( gastronomic, spiritual, indrustrial etc.)

- Cultural city tourism, cultural tours

- Traditions, ethnic tourism

- Event and festival tourism

- Religious tourism, pilgrimage routes

- Creative tourism ( cinema, the press, multimedia, etc.)

According to he the National Trustố definition of cultural heritage, tourism is ñtraveling to experience the places and activities that authentically represent the stories and people of the past and present. It includes historic, cultural and natural resources." Tourism is a powerful economic development tool. Tourism creates jobs, provides new business opportunities and strengthens local economies. When cultural heritage tourism development is done right, it also helps to protect our nationôs natural and cultural treasures and improve the quality of life for residents and visitors alike.

Linking tourism with heritage and culture can do more for local economies than promoting them separately. Thatôs the core idea in cultural heritage tourism: save your heritage and your culture, share it with visitors, and reap the economic benefits of tourism. (National Trust for Historic Preservation, 2011)

\section{World heritage}

Heritage is our legacy from the past, what we live with today, and what we pass on to future generations. Our cultural and natural heritage are both irreplaceable sources of life and inspiration. 
Places as unique and diverse as the wilds of East Africaô Serengeti, the Pyramids of Egypt, the Great Barrier Reef in Australia and the Baroque cathedrals of Latin America make up our worldô heritage.

The United Nations Educational, Scientific and Cultural Organization (UNESCO) seeks to encourage the identification, protection and preservation of cultural and natural heritage around the world considered to be of outstanding value to humanity. This is embodied in an international treaty called the Convention concerning the Protection of the World Cultural and Natural Heritage , adopted by UNESCO in 1972.(UNESCO, 2013)

UNESCO's World Heritage mission is to:

- encourage countries to sign the World Heritage Convention and to ensure the protection of their natural and cultural heritage;

- encourage States Parties to the Convention to nominate sites within their national territory for inclusion on the World Heritage List;

- encourage States Parties to establish management plans and set up reporting systems on the state of conservation of their World Heritage sites;

- help States Parties safeguard World Heritage properties by providing technical assistance and professional training, etc.

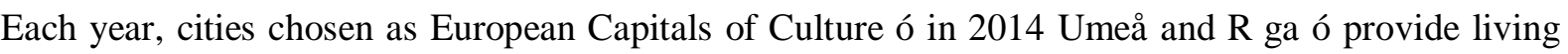
proof of the richness and diversity of European cultures. Started in 1985, the initiative has become one of the most prestigious and high-profile cultural events in Europe. More than 40 cities have been designated European Capitals of Culture so far, from Stockholm to Genoa, Athens to Glasgow, and Cracow to Porto.

The following future European Capitals of Culture have already been designated: (European Commission, 2013)

- 2014 Umeå (Sweden) and Riga (Latvia) (Sweden) and Riga (Latvia)

- 2015 Mons (Belgium) and PlzeŔ(Czech Republic)

- 2016 Donostia-San Sebastian (Spain) and Wrocă (Poland)

- 2017 Aarhus (Denmark) and Paphos (Cyprus)

- 2018 Valletta (Malta)

According to the UNESCO, The World Heritage List includes 981 properties forming part of the cultural and natural heritage which the World Heritage Committee considers as having outstanding universal value. These include 759 cultural, 193 natural and 29 mixed properties in 160 States Parties. As of September 2012, 190 States Parties have ratified the World Heritage Convention.

95 countries have an area designated as a natural or mixed World Heritage Site:

- 40 in Africa

- 6 in Arab States

- 67 in Asia and the Pacific

- 71 in Europe and North America

- 39 in Latin America and the Caribbean

The average area of a natural World Heritage Site is c. 1,263, 100 ha $(12,631 \mathrm{sq} \mathrm{km})$. Excluding the very large Phoenix Islands Protected Areas, Papah size is c. 727,000 ha $(7,270$ square kilometers). 
Tab. 1: The ten countries with the largest extent of natural World Heritage Sites

\begin{tabular}{|l|c|c|}
\hline \multicolumn{1}{|c|}{ Country } & $\begin{array}{c}\text { Total Area of natural } \\
\text { World Heritage Sites }\end{array}$ & $\begin{array}{c}\text { Area of natural World } \\
\text { Heritage Sites as \% of } \\
\text { national protected areas }\end{array}$ \\
\hline 1. United States of America & $46,341,817$ & $19 \%$ \\
\hline 2. Australia & $44,135,913$ & $27 \%$ \\
\hline 3. Kiribati & $40,825,000$ & $91 \%$ \\
\hline 4. Russian Federation & $22,436,659$ & $9 \%$ \\
\hline 5. Ecuador & $14,338,439$ & $73 \%$ \\
\hline 6. Canada & $10,608,213$ & $12 \%$ \\
\hline 7. Niger & $7,956,000$ & $96 \%$ \\
\hline 8.Algeria & $7,361,315$ & $52 \%$ \\
\hline 9. Tanzania & $7,200,000$ & $26 \%$ \\
\hline 10. Congo, The Democratic Republic & $6,670,671$ & $30 \%$ \\
\hline
\end{tabular}

Natural and cultural World Heritage sites are among the Worldôs most visited tourist attractions. Tourism and visitation to these sites has the potential to generate revenues that may benefit the protection of the sites as well as contribute to the livelihoods of the local communities living within and around the sites. However poorly managed tourism and development of visitor facilities may also represent a threat to the sites and their Outstanding Universal Values. For tourism and visitation, as well as public use related to World Heritage Sites to be sustainable and responsible we need to ensure that tourism related development as well as management is sustainable from an economic, social and environmental perspective. (Nordic World Heritage Foundation, 2013)

International tourist arrivals worldwide will increase by $3.3 \%$ a year from 2010 to 2030 to reach 1.8 billion by 2030 according to UNWTO long term forecast Tourism Towards 2030. Between 2010 and 2030 , arrivals in emerging destinations $(+4.4 \%$ a year) are expected to increase at double the pace of that in advanced economies $(+2.2 \%$ a year). The market share of emerging economies increased from $30 \%$ in 1980 to $47 \%$ in 2012 , and is expected to reach $57 \%$ by 2030 , equivalent to over one billion international tourist arrivals.

In 2012, travel for holidays, recreation and types of leisure accounted for just over half of all international tourist arrivals (52\% or 536 million arrivals). Some 14\% of international tourists reported travelling for business and professional purposes and another $27 \%$ travelled for other purposes, such as visiting friends and relatives (VFR), religious reasons and pilgrimages, health treatment, etc. The purpose of visit for the remaining 7\% of arrivals was not specified.(UNWTO, 2013)

Conclusion

The aim of this paper was evaluate cultural tourism in connection with World Heritage. Cultural tourism is essentially that form of tourism that focuses on the culture, and cultural environments including landscapes of the destination, the values and lifestyles, heritage, visual and performing arts, industries, traditions and leisure pursuits of the local population and host community. It can include attendance at cultural events, visits to museums and heritage places and mixing with local people. It should not be regarded as a definable niche within the broad range of tourism activities, but encompasses all experiences absorbed by the visitor to a place that is beyond their own living environment. (Kajzar, 2013)

The United Nations Educational, Scientific and Cultural Organization (UNESCO) seeks to encourage the identification, protection and preservation of cultural and natural heritage around the world considered to be of outstanding value to humanity. The idea of creating an international movement for 
protecting heritage emerged after World War I. Called the Convention concerning the Protection of the World Cultural and Natural Heritage, adopted by UNESCO in 1972.

Cultural tourism is all about experiences. Cultural tourists look for unforgettable holidays in destinations with the genius loci (the protective spirit of the place). Cultural tourists want to find out more about history of the place, people, monuments, the landscape that form them or engage in some cultural activities.

\section{Literature}

[1] BROOKS, G., (2011). Heritage as a driver for development. Paris: ICOMOS. [online]. [cit. 2014-1-28]. Available at: 〈http://openarchive.icomos.org/1207/1/III-1-Article1_Brooks.pdf〉>.

[2] CSAPÓ, J., (2012). The Role and Importance of Cultural Tourism in Modern Tourism Industry, Strategies for Tourism Industry - Micro and Macro Perspectives. In Tech. ISBN: 978-953-51-0566-4. Available at: $<\mathrm{http} / / / \mathrm{www}$.intechopen.com/books/strategies-for-tourism-industry-micro-and macroperspectives/the-roleand-importance-of-cultural-tourism-in-modern-tourism-industry>.

[3] EUROPEAN COMMISSION., (2013). Future European Capitals of Culture. [online]. [cit. 2014-3-5]. Available at: 〈http://ec.europa.eu/culture/our-programmes-and-actions/capitals/future-capitals_en.htm>.

[4] KAJZAR, P., (2013). Greece as cultural destination. In 16th International Colloquium on Regional Sciences. Brno: Masarykova univerzita. pp. 636-642. ISBN 978-80-210-6257-3. DOI 10.5817/CZ.MUNI.P210-6257-2013-80.

[5] NATIONAL TRUST FOR HISTORIC PRESEVATION, (2011). Getting Started: How to Succeed in Cultural Heritage Tourism [online]. [cit. 2014-3-1]. Available at: <http://www.culturalheritagetourism.org/howtogetstarted.htm>.

[6] NORDIC WORLD HERITAGE FOUNDATION, (2013). World Heritage and Tourism [online]. [cit. 2014-3-4]. Available at: 〈http://www.nwhf.no/index.cfm?oa=content.display\&con=140>.

[7] RICHARDS, G., (2005). Cultural Tourism in Europe. [online]. [cit. 2014-3-1]. Available at: $\langle$ http://www.tram-research.com/cultural_tourism_in_europe.pdf $>$.

[8] UICN, (2013). World Heritage Facts and Figures [online]. [cit. 2014-3-1]. Available at: <https://www.iucn.org/about/work/programmes/wcpa_worldheritage/resources/wcpa_whfacts/>.

[9] UNESCO, (2013). World Heritage. [online]. [cit. 2014-3-1]. Available at: $\langle$ http://whc.unesco.org/en/about>.

[10] UNWTO, (2013). Tourism Highlights. [online]. [cit. 2014-3-1]. Available at: $\langle$ http://dtxtq4w60xqpw.cloudfront.net/sites/all/files/pdf/unwto_highlights13_en_hr.pdf〉.

[11] WILLIAMS, P., (2010). Cultural Tourism and the UK City of Culture. [online]. [cit. 2014-2-7]. Available at: <http://www.insights.org.uk/articleitem.aspx?title=Cultural+Tourism+and+the+UK+City+of+Culture>.

[12] ZEDKOVÁ, A., KAJZAR, P., (2013). Cultural destinations as one of the most important generators of tourism. Scientific Papers of the University of Pardubice. Series D, vol. XX, iss. 29, pp. 191-202. ISSN 1804-8048.

This paper was supported by the Ministry of Education, Youth and Sports within the Institutional Support for Long-term Development of a Research Organization in 2014. 